\title{
In Vivo Inhibition of Renal Heme Oxygenase with an Imidazole- Dioxolane Inhibitor
}

\author{
Eva Csongradi ${ }^{1}$, Trinity Vera ${ }^{1}$, John M. Rimoldi ${ }^{2}$, Rama S.V. Gadepalli ${ }^{2}$, and David E. \\ Stec ${ }^{1, \#}$ \\ ${ }^{1}$ Department of Physiology \& Biophysics, Center for Excellence in Cardiovascular-Renal \\ Research, University of Mississippi Medical Center, 2500 N State St, Jackson, MS 39216. \\ ${ }^{2}$ Department of Medicinal Chemistry, The University of Mississippi, 331 Faser Hall, University, \\ MS 38677
}

\begin{abstract}
Recent studies have indentified imidazole-dioxolane based compounds as novel heme oxyenase (HO) inhibitors. While these compounds have been demonstrated to be specific HO inhibitors in vitro, they have yet to be used to inhibit renal $\mathrm{HO}$ activity in vivo. The goal of this study was to determine the effectiveness of the imidazole-dioxolane HO-1 inhibitor, QC-13, in the inhibition of renal $\mathrm{HO}$ activity in vivo. HO-1 was induced in mice by treatment with cobalt protoporphyrin (CoPP). After 5 days, QC-13 was delivered either by continuous intrarenal medullay interstitial infusion (IRMI) into one kidney at several concentrations for 72 hours or by two intraperitoneal injections over a 48 hour period. IRMI infusion of QC-13 at a concentration of $25 \mu \mathrm{M}$ resulted in a significant decrease in medullary but not cortical HO activity as compared to CoPP treated kidneys. IRMI infusion of QC-13 at a lower concentration $(2.5 \mu \mathrm{M})$ had no effect on either medullary or cortical HO activity in CoPP treated mice. In contrast, administration of QC-13 at a higher concentration $(250 \mu \mathrm{M})$ resulted in a significant decrease in both medullary and cortical $\mathrm{HO}$ activity in CoPP treated mice. Systemic administration of QC-13 resulted in significant decrease both renal cortical and medullary HO activity in CoPP treated mice. In contrast to classical porphyrin based HO inhibitors, IRMI infusion of QC-13 did not induce HO-1 protein levels as determined by Western blot analysis of medullary protein samples. Our results demonstrated that imidazole-dioxolane inhibitors are renal HO inhibitors in vivo and can inhibit $\mathrm{HO}$ activity independent of HO-1 induction. These inhibitors may be useful tools to elucidate the role of renal HO-1 in numerous physiologic and pathophysiologic conditions.
\end{abstract}

\section{Keywords}

Kidney; Carbon Monoxide; Cobalt Protoporyphrin; Heme Oxygenase-1; Mouse

\footnotetext{
(C) 2010 Elsevier Ltd. All rights reserved.

\#Correspondence: David E. Stec, Ph.D. Associate Professor Department of Physiology \& Biophysics University of Mississippi Medical Center Jackson, MS 39216 Phone: 601-815-1859 Fax: 601-984-1817 dstec@physiology.umsmed.edu.

Publisher's Disclaimer: This is a PDF file of an unedited manuscript that has been accepted for publication. As a service to our customers we are providing this early version of the manuscript. The manuscript will undergo copyediting, typesetting, and review of the resulting proof before it is published in its final citable form. Please note that during the production process errors may be discovered which could affect the content, and all legal disclaimers that apply to the journal pertain.
} 


\section{Introduction}

Heme oxygenase $(\mathrm{HO})$ is the rate limiting enzyme in the degradation of heme to biliverdin in which carbon monoxide (CO) is released [1]. Biliverdin is subsequently converted into bilirubin by biliverdin reductase. The beneficial actions of $\mathrm{HO}$ in the cardiovascular system have been demonstrated by studies in which HO-1 levels were induced either chemically or genetically. For example, several studies have demonstrated that induction of HO-1 lowers blood pressure in several rodent models of hypertension [2-5]. Additional studies have demonstrated that induction of HO-1 protects organs from ischemia-reperfusion injury [6-9].

Whereas HO-1 induction studies have revealed important information regarding the biology of HO-1, we have also learned much about the biology of HO-1 from inhibitor studies. The first class of inhibitors and the most widely used are porphyrin compounds. Porphyrins are ring like structures which can bind to metals and form metalloporphyrins which are potent HO inhibitors [10,11]. Metallopophyrin based HO inhibitors have been used widely to elucidate the function of HO-1; however, they have several limitations with their use in vivo. First, most metalloporphyrins are photosensitive and can breakdown upon exposure to light which makes working with them difficult [12]. Second, the specificity of these compounds can be an issue. Several studies have demonstrated that metalloporphyrins can inhibit other proteins such as nitric oxide synthase and soluble guanylyl cyclase especially when used at higher concentrations [13-15]. Lastly, while these compounds are inhibitors of HO activity, they are also very potent inducers of HO-1 due to the metal group associated with the porphyrin ring $[16,17]$. Imidazole-dioxolane HO inhibitors are a new class of compounds which have recently been reported to be specific inhibitors of $\mathrm{HO}$ in vitro $[18,19]$. These compounds offer a potential advantage in that they do not resemble heme, the natural $\mathrm{HO}$ substrate, and they do not contain metals which may induce HO-1. Recently, the effectiveness and specificity of imidazole-dioxolane inhibitors was demonstrated in cultures of proximal tubule cells [20]. Whether these compounds are effective $\mathrm{HO}$ inhibitors in the kidney has yet to be tested. In the present study, we determined for the first time if the imidazole-dioxolane $\mathrm{HO}$ inhibitor, $\mathrm{QC}-13$, is an effective in vivo inhibitor of renal $\mathrm{HO}$ activity.

\section{Methods}

\section{Animals}

Studies were performed on 16-20 week male C57BL/6J mice (Jackson Labs, Bar Harbor, ME). All studies were performed in accordance with the approval of the University of Mississippi Medical Center Institutional Animal Care and Use Committee (IACUC) and in line with NIH guidelines. Mice were treated with cobalt protoporphyrin (CoPP) as described below. After seven days, intramedullary interstitial catheters were implanted into the left kidney and saline infused through the catheter for a period of 2 days. After this time, the infusion was switched over to QC-13 for an additional 3 days. Mice were then euthanized for determination of $\mathrm{HO}$ activity. Intramedullary interstitial catheters were modified as previously described [21] and implanted 1.5-2 $\mathrm{mm}$ into the left kidney. QC-13 was also administered by intraperitoneal (ip) injection $(52 \mathrm{mg} / \mathrm{kg}$ ) which is equivalent to 10 times the $25 \mu \mathrm{M}$ concentration that was administered directly into the renal medulla. In this part of the study, mice were treated with CoPP as above. After 7 days, mice received single ip injections of QC-13 for two days and then were euthanized the next day and organs collected for determination of $\mathrm{HO}$ activity. 


\section{Drugs}

QC-13, $(2 R, 4 R)$-2-[2-(4-chlorophenyl)ethyl]-2-[(1H-imidazol-1-yl)methyl]-4-methyl-1,3dioxolane hydrochloride, was synthesized as previously described [18]. Stock solutions of QC-13 were prepared in distilled water and diluted in saline for intrarenal medullay interstitial infusion (IRMI) and ip injections. HO-1 was induced by a single treatment with CoPP (50 mg/kg body weight, sc, Frontier Scientific, Logan, UT) as previously described [5].

\section{Heme Oxygenase Assay}

Heme oxygenase assay was performed on tissue lysates prepared as previously described [5]. The protein concentration was measured using a Bio-rad protein assay with BSA standards. Reactions were carried out in a $1.2 \mathrm{mls}$ containing: $2 \mathrm{mM}$ glucose-6-phosphate, 0.2 units glucose-6-phosphate dehydrogenase, $0.8 \mathrm{mM} \mathrm{NADPH}, 20 \mu \mathrm{M}$ hemin, and $0.5 \mathrm{mg}$ of lysate. The reactions were incubated for 1 hour at $37^{\circ} \mathrm{C}$ in the dark. The formed bilirubin was extracted with chloroform, and the change in optical density $(\Delta \mathrm{OD})$ at $464-530 \mathrm{~nm}$ was measured using an extinction coefficient of $40 \mathrm{mM} / \mathrm{cm}$ for bilirubin. HO activity was calculated as picomoles of bilirubin formed per hour per milligram of microsomal protein. For the IRMI studies, HO activity is expressed as percentage of non-infused cortex or medulla.

\section{Western Blot}

Western Blot for HO-1and HO-2 proteins were performed on lysates prepared from the renal cortex and medulla. Samples of $30 \mu \mathrm{g}$ of protein were boiled in Laemmli sample buffer (Bio-Rad, Hercules, CA) for 5 min, electrophoresed on 12\% SDS-polyacrylamide gels, and blotted onto nitrocellulose membrane. Membranes were blocked with Odyssey blocking buffer (LI-COR, Lincoln, NE) for 2 hours at room temperature, then incubated with mouse anti-HO-1 antibody (StressGen, Vancouver, Canada, 1:2000) and rabbit anti- $\beta$-actin antibody (abcam, Cambridge, MA, 1:5,000) or rabbit anti-HO-2 polyclonal antibody (StressGen, Vancouver, Canada, 1:2000) and mouse anti- $\beta$ actin antibody (abcam, Cambridge, MA, 1:5,000) overnight at $4^{\circ} \mathrm{C}$. The membranes were then incubated with Alexa 680 goat anti-mouse IgG (Molecular Probes, Portland, OR, 1:5,000) and IRDye 800 goat anti-rabbit IgG (Rockland, Gilbertsville, PA, 1:5,000) or Alexa 680 donkey anti-rabbit IgG (Molecular Probes, Portland, OR, 1:5,000) or IRDye 800 donkey anti-mouse IgG (Rockland, Gilbertsville, PA, 1:5,000) for 1 hour at room temperature. The membranes were then visualized using an Odyssey infrared imager (Li-COR, Lincoln, NE). Experiments were performed in duplicated and densitometry analysis was performed using Odyssey software (LI-COR, Lincoln, NE). The level of HO protein is expressed as a ratio to the level of $\beta$ actin to normalize for protein loading.

\section{Statistics}

Mean values \pm Standard Error (SE) are presented. Significant differences between mean values were determined using an unpaired $\mathrm{T}$ test or by ANOVA followed by a post hoc test (Tukey). A $\mathrm{p}<0.05$ was considered to be significant.

\section{Results}

\section{Effect of Intrarenal Medullary Interstitial Infusion (IRMI) of QC-13 on HO Activity in CoPP Treated Mice}

IRMI infusion of QC-13 at a concentration of $25 \mu \mathrm{M}$ had no effect on $\mathrm{HO}$ activity in the medulla or cortex of control mice (Figure 1). This result is likely due to the low levels of HO-1 protein present in the kidney under basal conditions. In order to determine the 
effectiveness of QC-13 in inhibiting HO-1, mice were pre-treated with CoPP which is a strong inducer of HO-1 protein in vivo [5]. CoPP treatment resulted in a 3 fold increase in $\mathrm{HO}$ activity in both the renal cortex and medulla as compared to control levels (data not shown). The dose response curves of QC-13 on HO activity in the renal cortex and medulla of CoPP treated mice are presented in Figure 2. IRMI of QC-13 at a concentration of 2.5 or $25 \mu \mathrm{M}$ had no effect on renal cortical HO activity. HO activity averaged $106 \pm 17$ and $111 \pm$ $8 \%$ of that observed in the non-infused CoPP treated kidney (Figure 2A). IRMI infusion of QC-13 at a concentration of $250 \mu \mathrm{M}$ resulted in a significant decrease in renal cortical HO activity as compared to the non-infused CoPP treated kidney averaging $59 \pm 9 \%$ (Figure 2A).

IRMI of QC-13 at a concentration of $2.5 \mu \mathrm{M}$ had no effect on renal medullary $\mathrm{HO}$ activity in the infused kidney of CoPP treated mice averaging $105 \pm 11 \%$ (Figure 2B). However, IRMI of QC-13 at concentrations of 25 and $250 \mu \mathrm{M}$ resulted in significant decreases in medullary $\mathrm{HO}$ activity in the infused kidney of CoPP treated mice averaging $46 \pm 14$ and $38 \pm 7 \%$ of that observed in the non-infused CoPP treated kidney (Figure 2B).

\section{Effect of Intraperitoneal Injection QC-13 on HO Activity in CoPP Treated Mice}

In order to determine the effect of systemic administration of QC-13 on renal HO activity, CoPP treated mice were treated with two ip injections $(52 \mathrm{mg} / \mathrm{kg}$ ) over a 48 hour period. Systemic administration of QC-13 at this concentration resulted in a significant decrease in both renal cortical and medullary HO activity in CoPP treated mice as compared to nonQC-13 treated mice (Table 1). However, systemic administration of QC-13 at this concentration did not result in a significant decrease in $\mathrm{HO}$ activity in heart or liver of CoPP treated mice (Table 1).

\section{IRMI Infusion of QC-13 Does Not Induce HO-1 Protein}

In order to determine if IRMI infusion of QC-13 was associated with induction of HO-1 or HO-2 protein, Western blot was performed on lysates from the renal cortex and medulla of control mice in which QC-13 was infused via intrarenal medullary interstitial catheters as well as control, IRMI QC-13, CoPP, and CoPP + IRMI QC-13 mice. CoPP treatment resulted in a 10-fold increase in the level of HO-1 protein in the renal medulla (Figure 3). IRMI infusion of QC-13 did not induce HO-1 protein either in control or CoPP treated mice (Figure 3). Next, we determined the effect of IRMI infusion of QC-13 at several concentrations $(2.5,25$, and $250 \mu \mathrm{M})$ on the levels of HO- 1 and 2 protein in the cortex and medulla of the infused kidney. IRMI infusion of QC-13 at all concentrations tested had no effect on the levels of HO-1 or 2 protein in the renal cortex of infused mice (Figure 4). Likewise, IRMI infusion of QC-13 at all concentrations tested had no effect on the levels of HO-1 or 2 protein in the renal medulla of infused mice (Figure 5). These results indicate that unlike porphryrin-based $\mathrm{HO}$ inhibitors imidazole-dioxolane inhibitors do not induce HO-1 protein in vivo.

\section{Discussion}

The present study is the first to test the efficacy of the imidazole-dioxolane inhibitor, QC-13, in the in vivo inhibition of HO-1 in the kidney by either direct infusion into the renal medulla or by systemic administration. Our results demonstrate that when QC-13 was infused directly into the renal medulla of CoPP treated mice at a concentration of $25 \mu \mathrm{M}$ specific inhibition of medullary $\mathrm{HO}$ activity was observed. This concentration of QC-13 was based on the findings of a previous in vitro study which demonstrated that this concentration of QC-13 resulted in maximal inhibition of $\mathrm{HO}$ activity in cultured proximal tubule cells treated with hemin [20]. While direct medullary infusion of QC-13 at this concentration was 
able to inhibit $\mathrm{HO}$ activity in CoPP pretreated mice, no significant inhibition of $\mathrm{HO}$ activity was observed when infused into the renal medulla of control mice. One reason for this observation may be that under basal conditions HO-1 is expressed at very low levels in the kidney and the majority of $\mathrm{HO}$ activity present may be derived from HO-2 [5,22]. Previous studies in cultured renal proximal tubule cells have demonstrated that QC-13 is a specific inhibitor of HO-1 but not HO-2 while another imidazole-dioxolane inhibitor, QC-1, can inhibit both isoforms of $\mathrm{HO}$ [20].

IRMI of QC-13 at a lower concentration $(2.5 \mu \mathrm{M})$ did not result in inhibition of $\mathrm{HO}$ activity in the renal medulla and cortex of CoPP treated mice. However, IRMI infusion of QC-13 at a 100 fold higher concentration $(250 \mu \mathrm{M})$ resulted in significant inhibition of both renal medullary and cortical HO activity in CoPP treated mice. Classically, compounds that are infused into the renal medulla are selectively accumulated because of the efficient countercurrent exchanger in the vasa recta circulation [23]. When compounds are infused at very high concentrations as with $250 \mu \mathrm{M} \mathrm{QC}-13$, it is possible that excess accumulation of the compound increases the amount that gets reabsorbed by the peritubular capillaries resulting in increased levels of the compounds which are then able to diffuse into the cortex. Thus, it is important to always test activity in both regions of the kidney when administering drugs into the renal medullary interstitium to ensure the degree of inhibition in each region.

IRMI infusion at the $25 \mu \mathrm{M}$ concentration resulted in selective inhibition of renal medullary but not cortical HO activity. However, we found that systemic administration of QC-13 at 10 at times this concentration inhibited both renal cortical and medullary HO activity without having any effect on $\mathrm{HO}$ activity in the heart and liver. The reason for this observation is not known but may be due to the increased accumulation of QC-13 in the kidney upon being filtered from the blood. A portion of the QC-13 could then be reabsorbed by the tubule cells mainly in the cortex and to a lesser extent in the renal medulla to inhibit $\mathrm{HO}$ activity. QC-13 administered via IP injection at this dose may not have reached a high enough plasma concentration effectively inhibit $\mathrm{HO}$ activity in these organs. While we did observe a significant decrease in renal cortical and medullary $\mathrm{HO}$ activity with this dose of QC-13, the degree of inhibition was much greater (56\%) in the renal cortex as compared to the medulla (20\%). Thus, it may be possible to selectively inhibit medullary versus cortical $\mathrm{HO}$ activity with a lower dose of QC-13 in order to determine the role of $\mathrm{HO}$ in these different regions in various renal pathologies. For example, both renal ischemia and acute renal injury due to radiocontrast agents are believed to cause preferential damage to the renal medulla especially thick ascending loop of Henle cells $[24,25]$ while nephrotoxins such as cisplatin are believed to target proximal tubule cells in the cortex [26,27]. Several studies have suggested that induction of HO-1 may play a protective role in the response of the kidney to all of these pathological injuries [28-31]. Differential delivery methods as well as infusion of different concentrations of the imidazole-dioxolane inhibitor, QC-13, could be used as a strategy to target either medullary or cortical HO-1 to further investigate the protective role of HO-1 induction in each of these conditions.

The most widely used class of $\mathrm{HO}$ inhibitors are metalloporphyrin based compounds such as stannous mesoporphyrin, Zinc Deuteroporphyrin IX 2,4 Bis Etylene Glycol (ZnDPBG), and chromium mesoporphyrin (CrMP) [32-34]. While these compounds can block HO activity, they are also potent inducers due to the metal containing groups [16,17]. The induction of HO- 1 by these compounds could lead to decreased efficiency of blockade in vivo especially in situations in which these compounds are administered chronically. Imidazole-dioxolane inhibitors such as QC-13 offer a distinct advantage over metalloporphyrin based HO inhibitors in that they do not induce HO-1 in vivo which is less likely to complicate interpretation of data resulting from their chronic use. They are also water soluble and do not undergo photosensitization which also makes them easier to chronically infuse in vivo. 
In conclusion, the present study demonstrates that the imidazole-dioxolane inhibitor, QC-13, is an effective inhibitor of renal HO-1 in vivo. HO-1 activity in the renal medulla or cortex can be selectively blocked with QC-13 depending upon how the compound is delivered to the kidney. Systemic administration of QC-13 preferentially inhibits renal cortical HO-1 while direct infusion into the renal medulla at a concentration of $25 \mu \mathrm{M}$ selectively inhibits medullary HO-1 activity. Blockade of HO-1 with QC-13 is not associated with induction of endogenous HO-1 as observed with classical metalloporphyrin based HO inhibitors. Imidazole-dioxolane $\mathrm{HO}$ inhibitors have the potential to be excellent pharmacological tools to investigate the role of renal $\mathrm{HO}$ in a number of different physiological and pathological processes in the kidney.

\section{Acknowledgments}

These studies were supported by grants from the National Heart, Lung and Blood Institute HL088421, and HL088421-S1 (D.E.S.), and PO1HL-5197.

\section{References}

1. Abraham NG, Kappas A. Pharmacological and clinical aspects of heme oxygenase. Pharmacol Rev 2008;60:79-127. [PubMed: 18323402]

2. Yang L, Quan S, Nasjletti A, Laniado-Schwartzman M, Abraham NG. Heme oxygenase-1 gene expression modulates angiotensin II-induced increase in blood pressure. Hypertension 2004;43:1221-1226. [PubMed: 15166181]

3. Botros FT, Schwartzman ML, Stier CT Jr. Goodman AI, Abraham NG. Increase in heme oxygenase-1 levels ameliorates renovascular hypertension. Kidney Int 2005;68:2745-2755. [PubMed: 16316349]

4. Sabaawy HE, Zhang F, Nguyen X, ElHosseiny A, Nasjletti A, Schwartzman M, et al. Human heme oxygenase-1 gene transfer lowers blood pressure and promotes growth in spontaneously hypertensive rats. Hypertension 2001;38:210-215. [PubMed: 11509478]

5. Vera T, Kelsen S, Yanes LL, Reckelhoff JF, Stec DE. HO-1 induction lowers blood pressure and superoxide production in the renal medulla of angiotensin II hypertensive mice. Am J Physiol Regul Integr Comp Physiol 2007;292:R1472-R1478. [PubMed: 17194725]

6. Katori M, Buelow R, Ke B, Ma J, Coito AJ, Iyer S, et al. Heme oxygenase-1 overexpression protects rat hearts from cold ischemia/reperfusion injury via an antiapoptotic pathway. Transplantation 2002;73:287-292. [PubMed: 11821745]

7. Kato H, Amersi F, Buelow R, Melinek J, Coito AJ, Ke B, et al. Heme oxygenase-1 overexpression protects rat livers from ischemia/reperfusion injury with extended cold preservation. Am $\mathrm{J}$ Transplant 2001;1:121-128. [PubMed: 12099359]

8. Yet SF, Tian R, Layne MD, Wang ZY, Maemura K, Solovyeva M, et al. Cardiac-specific expression of heme oxygenase-1 protects against ischemia and reperfusion injury in transgenic mice. Circ Res 2001;89:168-173. [PubMed: 11463724]

9. Shimizu H, Takahashi T, Suzuki T, Yamasaki A, Fujiwara T, Odaka Y, et al. Protective effect of heme oxygenase induction in ischemic acute renal failure. Crit Care Med 2000;28:809-817. [PubMed: 10752834]

10. Kappas A, Drummond GS, Simionatto CS, Anderson KE. Control of heme oxygenase and plasma levels of bilirubin by a synthetic heme analogue, tin-protoporphyrin. Hepatology 1984;4:336-341. [PubMed: 6546735]

11. Anderson KE, Simionatto CS, Drummond GS, Kappas A. Tissue distribution and disposition of tin-protoporphyrin, a potent competitive inhibitor of heme oxygenase. J Pharmacol Exp Ther 1984;228:327-333. [PubMed: 6546399]

12. Vreman HJ, Ekstrand BC, Stevenson DK. Selection of metalloporphyrin heme oxygenase inhibitors based on potency and photoreactivity. Pediatr Res 1993;33:195-200. [PubMed: 8433895] 
13. Appleton SD, Chretien ML, McLaughlin BE, Vreman HJ, Stevenson DK, Brien JF, et al. Selective inhibition of heme oxygenase, without inhibition of nitric oxide synthase or soluble guanylyl cyclase, by metalloporphyrins at low concentrations. Drug Metab Dispos 1999;27:1214-1219. [PubMed: 10497150]

14. Ignarro LJ, Ballot B, Wood KS. Regulation of soluble guanylate cyclase activity by porphyrins and metalloporphyrins. J Biol Chem 1984;259:6201-6207. [PubMed: 6144676]

15. Meffert MK, Haley JE, Schuman EM, Schulman H, Madison DV. Inhibition of hippocampal heme oxygenase, nitric oxide synthase, and long-term potentiation by metalloporphyrins. Neuron 1994;13:1225-1233. [PubMed: 7524564]

16. Cable EE, Gildemeister OS, Pepe JA, Lambrecht RW, Bonkovsky HL. Mechanism of induction of heme oxygenase by metalloporphyrins in primary chick embryo liver cells: evidence against a stress-mediated response. Mol Cell Biochem 1997;169:13-20. [PubMed: 9089626]

17. Shan Y, Pepe J, Lu TH, Elbirt KK, Lambrecht RW, Bonkovsky HL. Induction of the heme oxygenase-1 gene by metalloporphyrins. Arch Biochem Biophys 2000;380:219-227. [PubMed: 10933875]

18. Vlahakis JZ, Kinobe RT, Bowers RJ, Brien JF, Nakatsu K, Szarek WA. Imidazoledioxolane compounds as isozyme-selective heme oxygenase inhibitors. J Med Chem 2006;49:4437-4441. [PubMed: 16821802]

19. Kinobe RT, Vlahakis JZ, Vreman HJ, Stevenson DK, Brien JF, Szarek WA, et al. Selectivity of imidazole-dioxolane compounds for in vitro inhibition of microsomal haem oxygenase isoforms. Br J Pharmacol 2006;147:307-315. [PubMed: 16331285]

20. Kinobe RT, Ji Y, Vlahakis JZ, Motterlini R, Brien JF, Szarek WA, et al. Effectiveness of novel imidazole-dioxolane heme oxygenase inhibitors in renal proximal tubule epithelial cells. J Pharmacol Exp Ther 2007;323:763-770. [PubMed: 17761847]

21. Vera T, Kelsen S, Stec DE. Kidney-specific induction of heme oxygenase-1 prevents angiotensin II hypertension. Hypertension 2008;52:660-665. [PubMed: 18695146]

22. Stec DE, Vera T, Storm MV, McLemore GR Jr. Ryan MJ. Blood pressure and renal blow flow responses in heme oxygenase-2 knockout mice. Am J Physiol Regul Integr Comp Physiol 2009;297:R1822-R1828. [PubMed: 19846746]

23. Lu S, Roman RJ, Mattson DL, Cowley AW Jr. Renal medullary interstitial infusion of diltiazem alters sodium and water excretion in rats. Am J Physiol 1992;263:R1064-R1070. [PubMed: 1443224]

24. Heyman SN, Fuchs S, Brezis M. The role of medullary ischemia in acute renal failure. New Horiz 1995;3:597-607. [PubMed: 8574590]

25. Yamamoto K, Wilson DR, Baumal R. Outer medullary circulatory defect in ischemic acute renal failure. Am J Pathol 1984;116:253-261. [PubMed: 6465286]

26. Vickers AE, Rose K, Fisher R, Saulnier M, Sahota P, Bentley P. Kidney slices of human and rat to characterize cisplatin-induced injury on cellular pathways and morphology. Toxicol Pathol 2004;32:577-590. [PubMed: 15603542]

27. Taguchi T, Nazneen A, Abid MR, Razzaque MS. Cisplatin-associated nephrotoxicity and pathological events. Contrib Nephrol 2005;148:107-121. [PubMed: 15912030]

28. Goodman AI, Olszanecki R, Yang LM, Quan S, Li M, Omura S, et al. Heme oxygenase-1 protects against radiocontrast-induced acute kidney injury by regulating anti-apoptotic proteins. Kidney Int 2007;72:945-953. [PubMed: 17667987]

29. Agarwal A, Balla J, Alam J, Croatt AJ, Nath KA. Induction of heme oxygenase in toxic renal injury: a protective role in cisplatin nephrotoxicity in the rat. Kidney Int 1995;48:1298-1307. [PubMed: 8569092]

30. Shiraishi F, Curtis LM, Truong L, Poss K, Visner GA, Madsen K, et al. Heme oxygenase-1 gene ablation or expression modulates cisplatin-induced renal tubular apoptosis. Am J Physiol Renal Physiol 2000;278:F726-F736. [PubMed: 10807584]

31. Toda N, Takahashi T, Mizobuchi S, Fujii H, Nakahira K, Takahashi S, et al. Tin chloride pretreatment prevents renal injury in rats with ischemic acute renal failure. Crit Care Med 2002;30:1512-1522. [PubMed: 12130972] 
32. Rodriguez F, Kemp R, Balazy M, Nasjletti A. Effects of exogenous heme on renal function: role of heme oxygenase and cyclooxygenase. Hypertension 2003;42:680-684. [PubMed: 12900432]

33. Zou AP, Billington H, Su N, Cowley AW Jr. Expression and actions of heme oxygenase in the renal medulla of rats. Hypertension 2000;35:342-347. [PubMed: 10642322]

34. Li N, Yi F, Dos Santos EA, Donley DK, Li PL. Role of renal medullary heme oxygenase in the regulation of pressure natriuresis and arterial blood pressure. Hypertension 2007;49:148-154. [PubMed: 17075028] 


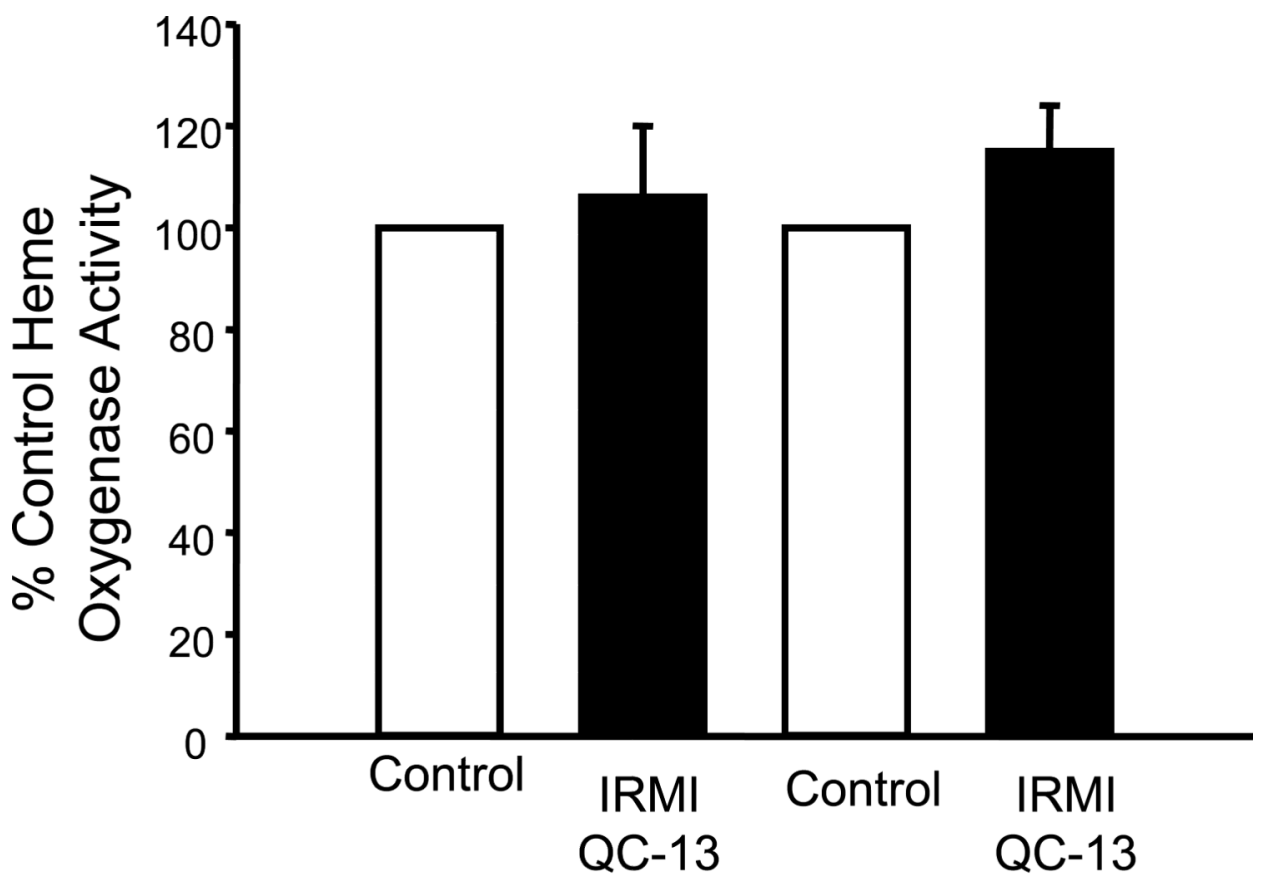

Figure 1.

Effect of intrarenal medullary interstitial infusion of QC-13 $(25 \mu \mathrm{M})$ on renal medullary and cortical heme oxygenase activity in control mice. QC-13 was infused for two dyas and HO assays were performed as described in the Methods. HO activity is expressed as the percent of activity observed in the control non-infused kidney, $n=7$. 


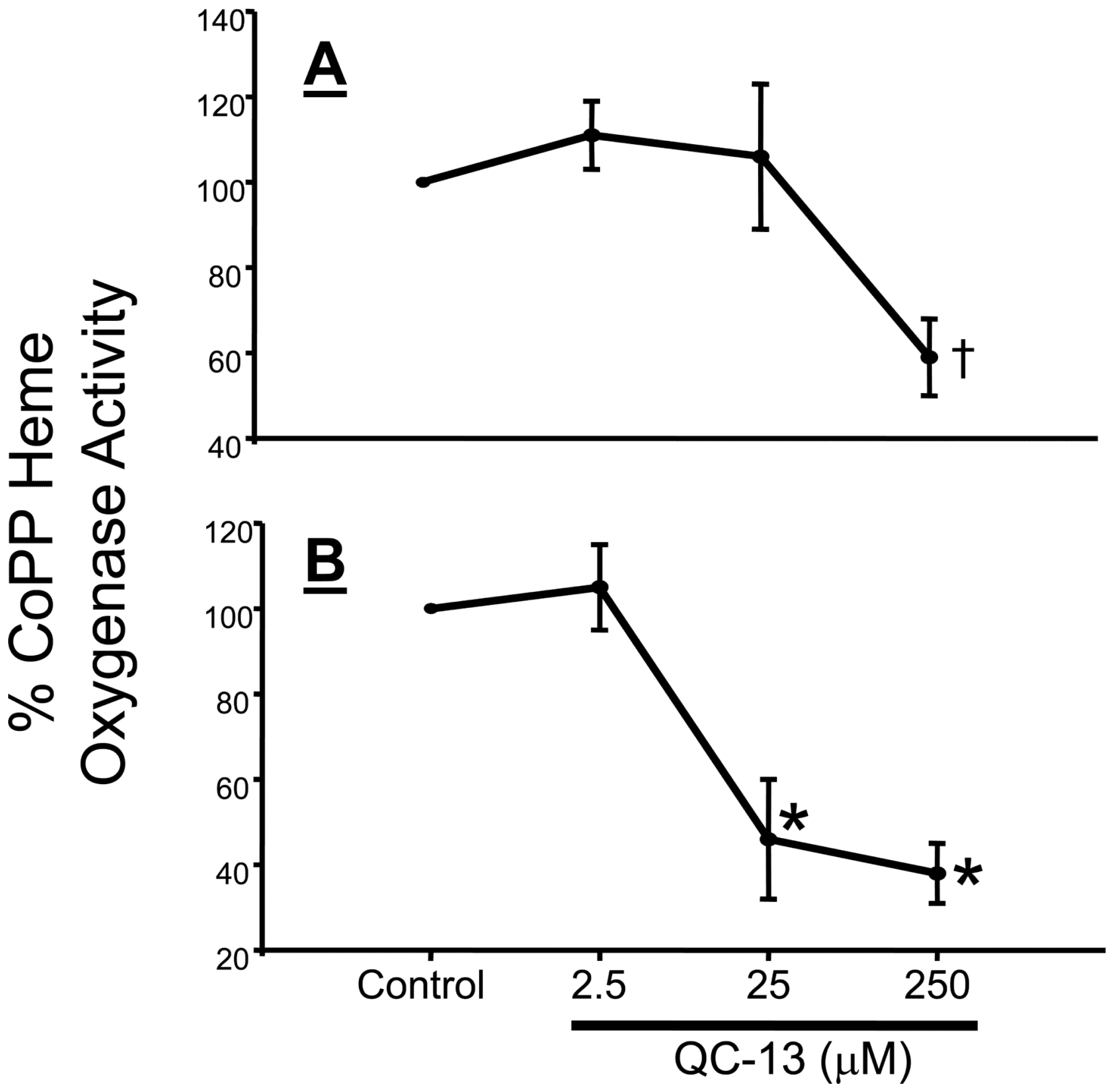

Figure 2.

Dose response curves of intrarenal medullary interstitial infusion of QC-13 $(2.5,25,250$ $\mu \mathrm{M}$ ) on A) renal cortical and B) renal medullary heme oxygenase activity in CoPP treated mice. Mice were administered a single dose of CoPP seven days prior to QC-13 infusion. QC-13 was then infused for two days and HO assays were performed as described in the Methods. HO activity is expressed as the percent of activity observed in the non-infused CoPP treated kidney, $\mathrm{n}=6 . \dagger=$ statistically different at $P<0.004 . *=$ statistically different at $P<0.001$. 


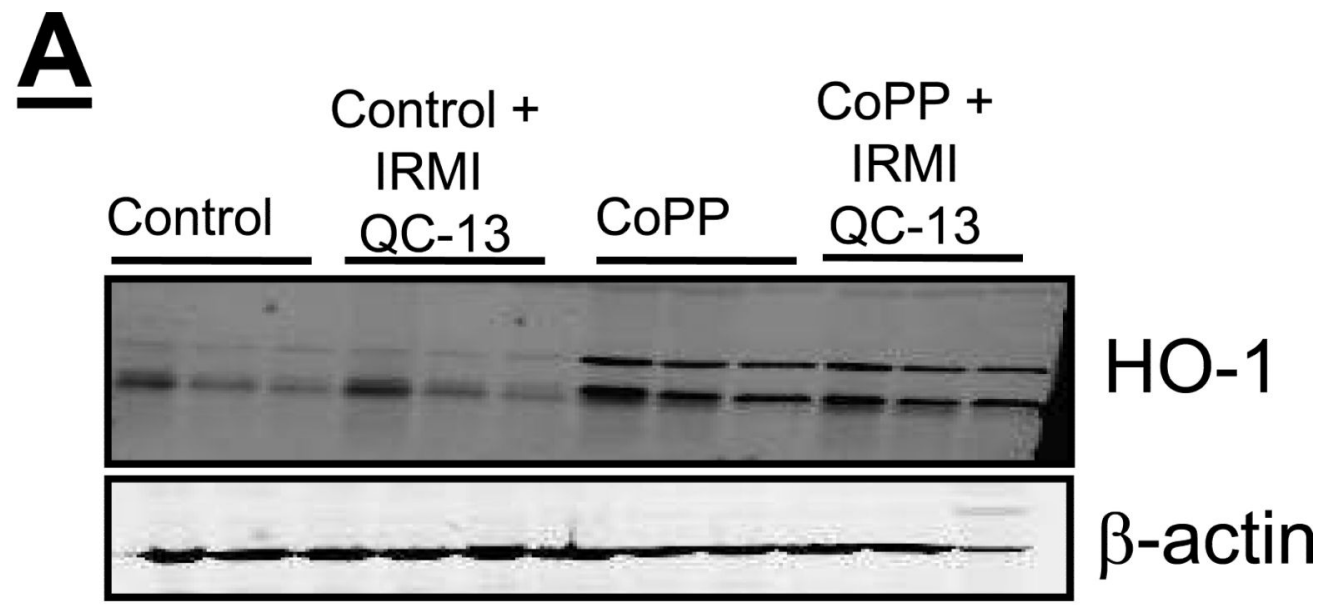

B

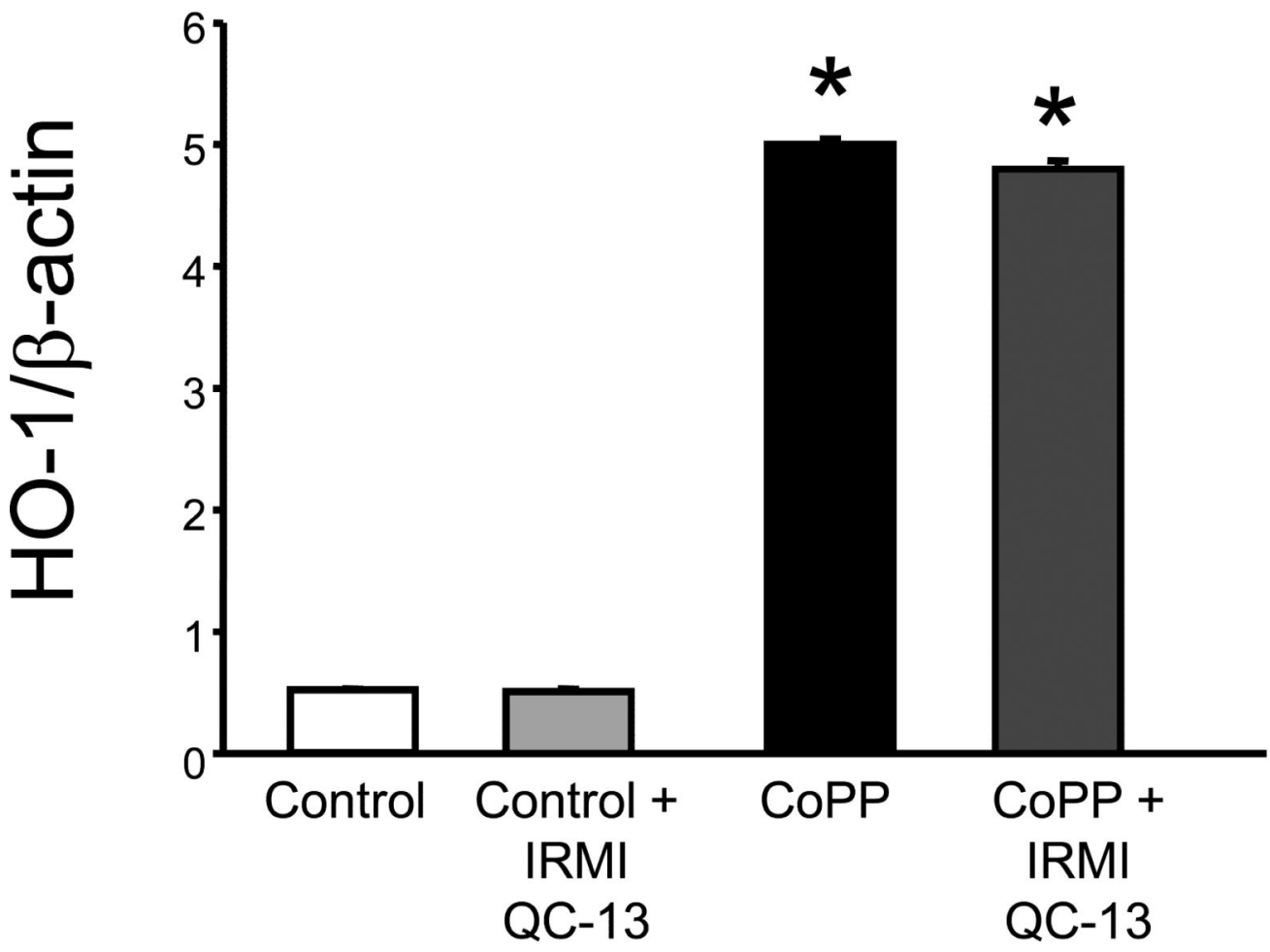

Figure 3.

Western blot of renal medullary lysates from control, control + intrarenal medullary interstitial infusion (IRMI) QC-13 $(25 \mu \mathrm{M}), \mathrm{CoPP}, \mathrm{CoPP}+$ IRMI QC-13 treated mice. A) Representative blot of HO-1 and $\beta$-actin from $30 \mu \mathrm{g}$ of tissue lysate. B) Quantitation of the level of HO-1 protein. The level of HO-1 protein is expressed as a ratio to the level of $\beta$ actin, $n=3 . *=$ statistically different at $\mathrm{p}<0.05$ by ANOVA followed by a post hoc test (Tukey). 

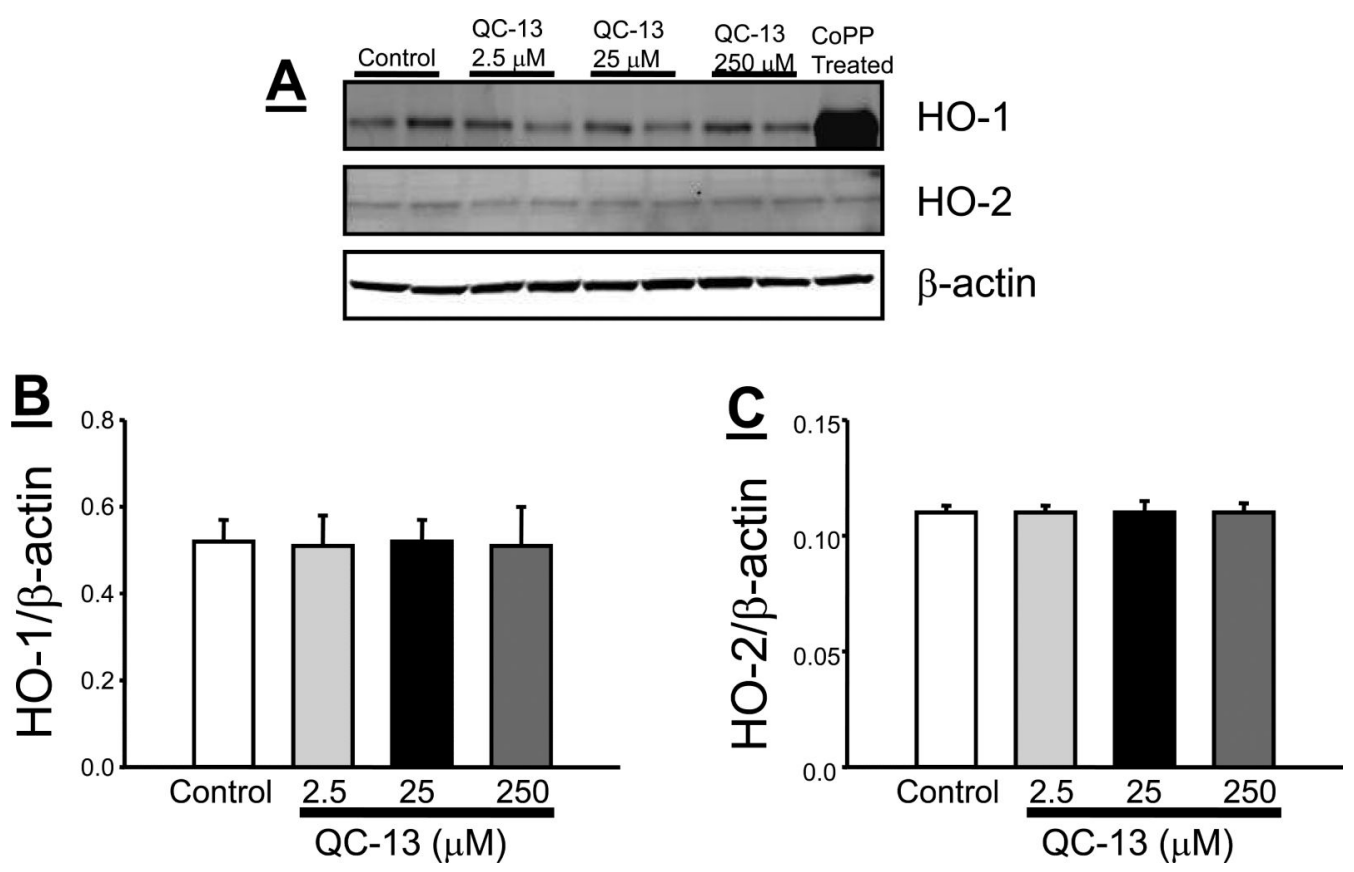

Figure 4.

Western blot of renal cortical HO-1 and HO-1 proteins from QC-13 infused mice. A) Representative blots of HO-1, HO-2, and $\beta$-actin from the renal cortex of QC-13 treated mice. QC-13 was infused via intrarenal medullary interstitial catheters for two days after which time kidneys were collected for protein measurements. B) Quantitation of the level of HO-1 protein. The level of HO-1 protein is expressed as a ratio to the level of $\beta$-actin, $n=4$. C) Quantitation of the level of HO-2 protein. The level of HO-2 protein is expressed as a ratio to the level of $\beta$-actin, $n=4$. 

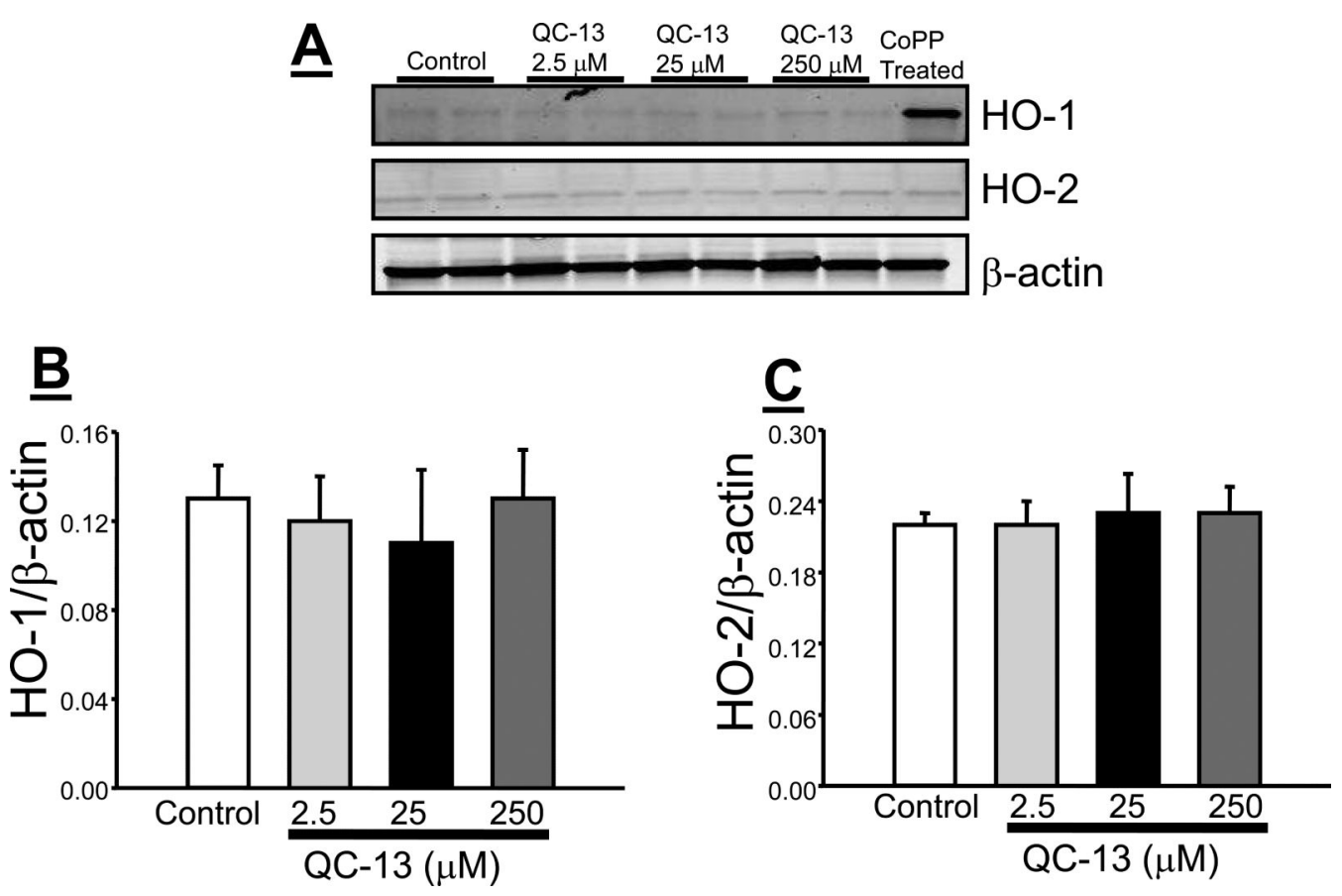

Figure 5.

Western blot of renal medullary HO-1 and HO-1 proteins from QC-13 infused mice. A) Representative blots of HO-1, HO-2, and $\beta$-actin from the renal medulla of QC-13 treated mice. QC-13 was infused via intrarenal medullary interstitial catheters for two days after which time kidneys were collected for protein measurements. B) Quantitation of the level of HO-1 protein. The level of HO-1 protein is expressed as a ratio to the level of $\beta$-actin, $n=4$. C) Quantitation of the level of HO-2 protein. The level of HO-2 protein is expressed as a ratio to the level of $\beta$-actin, $n=4$. 


\section{Table 1}

Effect of intraperitoneal injection of QC-13 (52/mg/kg) on HO activity in CoPP Treated Mice.

\begin{tabular}{lll}
\hline & \multicolumn{2}{l}{ Heme Oxygenase Activity } \\
Organ & CoPP & CoPP + QC-13 \\
Heart & $35+15$ & $24+7$ \\
Liver & $250+64$ & $195+26$ \\
Renal Cortex & $219+38$ & $98+27^{*}$ \\
Renal Medulla & $51+6$ & $41+2^{*}$ \\
\hline
\end{tabular}

Heme oxygenase activity given as pmoles bilirubin per hr per milligram of protein.

p $<0.05$ as compared to CoPP treated mice. $n=6$ per group. 